\title{
Kadar Hambat Minimum (KHM) dan Kadar Bunuh Minimum (KBM) Ekstrak Etanol Daun Ketepeng Cina (Cassia alata L.) Terhadap Pertumbuhan Candida albicans
}

\author{
Gharnita $\mathrm{YS}^{1}$, Lelyana $\mathrm{S}^{1}$, Sugiaman $\mathrm{VK}^{1}$ \\ Fakultas Kedokteran Gigi, Universitas Kristen Maranatha, Bandung, 40164, Indonesia \\ Email: shailla.yassie@gmail.com
}

\begin{abstract}
Abstrak
Candida albicans merupakan jamur dimorfik oportunistik penyebab utama oral candidiasis. Salah satu obat oral candidiasis yang suing digunakan adalah nistatin namun memiliki banyak efek samping maka dibutuhkan pengobatan alternatif dengan memanfaatkan tanaman herbal seperti daun ketepeng cina (Cassia alata L.). Penelitian ini bertujuan untuk mengetahui kadar hambat minimum (KHM) dan kadar bunuh minimum (KBM) ekstrak etanol daun ketepeng cina (Cassia alata L.) terhadap pertumbuhan Candida albicans dengan menghitung jumlah yeast.

Penelitian ini bersifat eksperimental laboratorium dengan membandingkan kelompok uji yang mengandung ekstrak daun ketepeng cina (Cassia alata L.) dengan konsentrasi $200 \mathrm{mg} / \mathrm{mL} ; 100 \mathrm{mg} / \mathrm{mL} ; 50 \mathrm{mg} / \mathrm{mL} ; 25 \mathrm{mg} / \mathrm{mL} ; 12,5 \mathrm{mg} / \mathrm{mL} ; 6,25$ $\mathrm{mg} / \mathrm{mL}$ dan $3,125 \mathrm{mg} / \mathrm{mL}$ yang ditanam dalam media PDA. Kontrol positif berupa nistanin, dan media PDB sedangkan kontrol negatif berupa media PDB, dan DMSO 10\% terhadap Candida albicans yang sebelumnya telah diinkubasi pada suhu $37^{\circ} \mathrm{C}$ selama 24 jam dan dilakukan pengulangan sebanyak empat kali.

Berdasarkan basil penelitian diketahui bahwa ekstrak etanol daun ketepeng cina (Cassia alata L.) mampu menghambat pertumbuhan Candida albicans pada konsentrasi $200 \mathrm{mg} / \mathrm{mL}$ secara sig $(\mathrm{p}<0,05)$ namun tidak dapat membunuh Candida albicans.

Simpulan dari penelitian ini menunjukkan bahwa ekstrak etanol daun ketepeng cina (Cassia alata L.) dapat menghambat pertumbuhan Candida albicans.
\end{abstract}

\section{The Minimum Inhibitory Content (MC) and Minimum Kill Content (MKC) Ethanol Extract Of Chinese Ketepeng Leaves (Cassia alata L.) on The Growth of Candida albicans}

\begin{abstract}
Candida albicans is an opportunistic dimorphic fungus which is the main cause of oral candidiasis. One of the commonly used oral candidiasis drugs is nystatin, but has many side effects, so alternative treatments are needed by utilizing herbal plants such as chinese ketepeng leaves (Cassia alata L.). This study aims to determine the minimum inhibitory content (MC) and minimum kill content $(M K C)$ ethanol extract of chinese ketepeng leaves (Cassia alata L.) on the growth of Candida albicans by calculating the amount of yeast.

This study was an experimental laboratory by comparing the test group containing chinese ketepeng leaves extract (Cassia alata L.) with concentration of $200 \mathrm{mg} / \mathrm{mL} ; 100 \mathrm{mg} / \mathrm{mL} ; 50 \mathrm{mg} / \mathrm{mL} ; 25 \mathrm{mg} / \mathrm{mL} ; 12,5 \mathrm{mg} / \mathrm{mL} ; 6,25$ $\mathrm{mg} / \mathrm{mL}$ and 3,125 mg/mL planted in FDA media. Positive controls in the form of Nystatin, and media PDB, while negative controls in the form of media PDB, and DMSO $10 \%$ against Candida albicans were previously incubated at $37^{\circ} \mathrm{C}$ for 24 hours and repeated four times.

Based on the results of the study it was found that the ethanol extract of chinese ketepeng leaves (Cassia alata L.) was able to inhibit the growth of Candida albicans at concentration $200 \mathrm{mg} / \mathrm{mL}$ sig (p <0.05) but could not kill Candida albicans.

Conclusions from this study indicate that the ethanol extract of chinese ketepeng leaves (Cassia alata L.) can inhibit the growth of Candida albicans.
\end{abstract}

Keywords: Candida albicans; Ethanol extract of chinese ketepeng leaves (Cassia alata L.) 


\section{Pendahuluan}

Rongga mulut merupakan pintu gerbang pertama pada sistem pencernaan. Makanan dan minuman akan diproses di dalam mulut dengan bantuan gigi, lidah, saliva dan otot. Rongga mulut juga memiliki berbagai fungsi, yaitu sebagai mastikasi, fonetik, dan estetik. Maka dari itu, rongga mulut merupakan tempat yang paling rawan dari tubuh karena sebagai pintu masuknya berbagai agen berbahaya, seperti bakteri, jamur dan virus.

Salah satu penyakit yang sudah tidak asing asing lagi adalah oral candidiasis. Oral candidiasis merupakan infeksi oportunistik dalam rongga mulut yang terjadi karena perubahan lingkungan rongga mulut dan mengakibatkan peningkatan jumlah Candida albicans. Hasil penelitian menunjukkan selama periode 2010 hingga 2014 sebanyak 49 orang pasien yang datang ke klinik ilmu penyakit mulut RSHS ditemukan oral candidiasis. Prevalensi terbanyak adalah pria sebesar 34 orang $(69,3 \%)$ dan wanita 15 orang $(30,7 \%)$, dengan faktor predisposisi terbanyak adalah keterlibatan penyakit sistemik sebesar 40,2\%. ${ }^{1,2}$

Pertumbuhan Candida albicans dalam rongga mulut dapat meningkat pada penggunaan kortikosteroid, penggunaan antibiotik spektrum luas jangka panjang, kadar glukosa darah yang tinggi, dan keadaan defisiensi sistem imun. ${ }^{3}$

Candida albicans merupakan agen penyebab utama pada oral candidiasis yang menimbulkan rasa sakit dan pedih pada rongga mulut, biasanya menetap di permukaan atas lidah bagian belakang (posterior). ${ }^{4}$ Bentuk lesi dari oral candidiasis yang paling sering ditemukan di dalam rongga mulut adalah pseudomembran dan eritematosus. ${ }^{1,3,5}$ Bahaya dari pseudomembran yaitu apabila lesi putih tersebut diangkat, maka akan terbentuk erosi perdarahan kecil sedangkan eritematosus dapat menimbulkan rasa sakit dan dapat bertahan cukup lama. ${ }^{6,7}$

Obat yang biasa digunakan untuk mengatasi Candida albicans adalah obat antijamur golongan poliena (seperti: nistatin, amfoterisin B). ${ }^{8}$ Nistatin merupakan obat antijamur yang bekerja lokal, tidak diabsorpsi sistemik, dan diisolasi dari bakteri Streptomyces noursei. Nistatin bekerja dengan mengikat ergosterol yang merupakan komponen utama dinding sel jamur. Pada konsentrasi yang cukup, nistatin akan membentuk pori pada membran sel jamur yang menyebabkan kebocoran kalium dan kematian sel jamur. ${ }^{9}$ Nistatin tersedia dalam bentuk suspensi, krim, salep, dan tablet vagina. ${ }^{10,11}$ Namun ada kendala yang timbul akibat penggunaan nistatin, yaitu harga yang dapat dikatakan relatif mahal dan menyebabkan efek samping seperti mual, muntah, diare, dan nyeri lambung serta resistensi. Menurut penelitian Zahra dkk (2017) Candida albicans resistensi terhadap nistatin sekitar 66,7\%. Oleh karena itu, 
kini ingin dikembangkan pengobatan alternatif dengan harga yang terjangkau dan efek samping yang minimal sehingga dapat dimanfaatkan oleh semua kalangan. ${ }^{10,12,13}$

Indonesia memiliki kekayaan alam yang berlimpah, yang dapat dimanfaatkan sebagai obat tradisional untuk masyarakat. Akhir-akhir ini penggunaan tanaman obat tradisional sebagai bahan pilihan pengobatan sehari-hari kembali meningkat, salah satu bahan alam yang memiliki potensi untuk diteliti adalah daun ketepeng cina (Cassia alata L.). ${ }^{14}$

Ketepeng cina memiliki nama daerah seperti Ki manila dari Sunda, Acong-acong dari Madura, Kupang-kupang dari Ternate, dan Tabakun dari Tidore. ${ }^{15}$ Ketepeng cina telah dimanfaatkan oleh masyarakat sebagai anti parasit, laktan, anti helminth, kudis, influenza, dan malaria. ${ }^{16}$ Ekstrak daun ketepeng cina digunakan sebagai bahan antibakteri karena mengandung senyawa fitokimia berupa tannin, flavonoid, tarpenoid, glikosida, dan steroid. ${ }^{17}$ Selain sebagai bahan antibakteri, ekstrak etanol dan akuades daun ketepeng cina juga dimanfaatkan sebagai zat antipiretik. ${ }^{18}$ Kandungan flavonoid pada tanaman herbal memiliki efek antiinflamasi, antialergi, antimikroba, antioksidan, dan efektik sebagai antifungsi untuk beberapa golongan jamur. ${ }^{14,19}$ Berdasarkan hasil penelitin yang dilakukan oleh Putri dkk. (2011) menyebutkan bahwa ekstrak daun ketepeng cina dengan konsentrasi 50\% sebanding dengan ketokonazol 2\% dalam menghambat pertumbuhan jamur Malassezia furfur pada Pityriasis versicolor secara in vitro. ${ }^{15,20}$

Hasil penelitian sebelumnya oleh Muhammad Bahi dkk. (2014) menunjukkan bahwa subfraksi D dari ekstrak $n$-heksana daun ketepeng cina (Cassia. Alata L.) menunjukkan aktivitas anti jamur terhadap Candida albicans pada konsentrasi 10\%, 30\%, dan 50\% dengan zona hambatnya masing-masing yaitu 10,$6 ; 11,3$; dan $12,6 \mathrm{~mm}^{21}$

Identifikasi masalah penelitian ini adalah Berapa kadar hambat minimum (KHM) ekstrak etanol daun ketepeng cina (Cassia alata L.) terhadap pertumbuhan Candida albicans; dan berapa kadar bunuh minimum (KBM) ekstrak etanol daun ketepeng cina (Cassia alata L.) terhadap pertumbuhan Candida albicans.

Tujuan penelitian ini adalah untuk mengetahui kadar hambat minimum (KHM) dan kadar bunuh minimum (KBM) ekstrak etanol daun ketepeng cina (Cassia alata L.) terhadap pertumbuhan Candida albicans.

Ketepeng cina (Cassia alata L.) memiliki beberapa nama tergantung dari daerah tempat tumbuhnya tanaman. Nama daerah ketepeng cina (Cassia alata L.) adalah Ki Manila dari Sunda; acong-acong dari Madura; kupang-kupang dari Ternate; tabakun dari Tidore.

Ketepeng cina (Cassia alata L.) berasal dari daerah tropik Amerika dan biasanya hidup pada 
dataran rendah sampai pegunungan dengan ketinggian 1.400 meter di atas permukaan laut. Tumbuhan ketepeng cina termasuk tumbuhan dikotil yang mempunyai sistem perakaran tunggang, yaitu memperlihatkan akar pokoknya yang bercabang-cabang menjadi akar yang lebih kecil dan berbentuk kerucut panjang yang terus tumbuh lurus ke bawah. Sistem perakaran tunggang ini umumnya berfungsi untuk memperluas bidang penyerapan dan memperkuat tegaknya batang. ${ }^{24,33}$

Kandungan kimia pada tumbuhan cina antara lain glikosida, flavonoid, tannin, triterpenoid/steroid, saponin dan turunan antrakuinon seperti krisarobin glukosida, krisofanol, asam krisofonat, rein aloe-emodina serta rein aloe-emodia-diantron. Selain itu, kandungan kimia pada daunnya adalah alkaloid, saponin, flavonoid, tannin, dan antrakuinon. ${ }^{34,35}$

Candida albicans telah dikenal dan dipelajari sejak abad ke-18 yang menyebabkan penyakit yang dihubungkan dengan hygiene yang buruk. Nama Candida albicans diperkenalkan pada Third International Microbiology Congress di New York pada tahun 1938, dan dibakukan pada Eight Botanical Congress di Paris pada tahun 1954. ${ }^{39}$

Candida albicans merupakan jamur yang bersifat oportunistik yang dapat ditemui pada kulit, mukosa mulut, usus, serta saluran reproduksi dalam kondisi normal dan tidak berbahaya. Jamur ini dapat menyebabkan infeksi pada mulut, kulit dan vagina apabila terjadi ketidakseimbangan bakteri. Candida albicans adalah jamur dimorphic gram positif yang mampu hidup di rongga mulut orang sehat. Lokasi primer dari Candida albicans adalah pada posterior lidah dan jaringan mukosa, sedangkan lokasi sekundernya pada lapisan yang menutupi gigi. Ketika sistem pertahanan tubuh terganggu akibat adanya perubahan, seperti imunodefisiensi, Candida albicans menjadi ganas dan dapat mengakibatkan Candidiasis yang dapat dimanifestasikan melalui berbagai bentuk klinis. ${ }^{40}$

Oral Candidiasis adalah infeksi jamur (adanya infeksi parasit pada bagian tubuh manapun) yang disebabkan oleh salah satu spesies dari Candida, diantaranya Candida albicans adalah spesies penyebab yang paling umum. Oral candidiasis adalah infeksi oportunistik umum dari rongga mulut yang disebabkan oleh pertumbuhan berlebih spesies Candida, yang paling umum adalah Candida albicans. Insiden bervariasi tergantung pada usia dan faktor predisposisi tertentu. Ada tiga kelompok besar terdiri dari Candidiasis akut, Candidiasis kronik, dan Angular cheilitis. Faktor risiko termasuk gangguan fungsi kelenjar saliva, obat-obatan, gigi tiruan, diet karbohidrat tinggi, merokok, diabetes mellitus, Cushing's syndrome, keganasan, dan kondisi immunocompromised. ${ }^{48,49}$

Infeksi Candida memiliki berbagai manifestasi tergantung dari lokasi. Sebagai contoh, oral 
candidiasis (thrush) hadir seperti plak putih yang timbul pada mukosa oral, lidah atau gusi. Oral Candidiasis dibagi menjadi infeksi primer dan sekunder. Infeksi primer terbatas pada bagian rongga mulut dan perioral, sedangkan infeksi sekunder diikuti dengan manifestasi mukokutaneus sistemik. Macam-macam Oral Candidiasis lainnya, yaitu Pseudomembraneous candidiasis (thrush), Chronic hyperplastic candidiasis (mukosa bukal), Chronic atrophic candidiasis (denture stomatitis), Median rhomboid glossitis (dari lidah bagian anterior sampai papilla sirkumpalata), dan Angular cheilitis (kedua sisi mulut bagian luar). ${ }^{48}$

\section{Metode Penelitian}

Alat penelitian yang dipergunakan dalam penelitian ini adalah: Mikropipet (50-200 $\mu \mathrm{L})$ (Eppendorf); Tips (50-200 $\mu \mathrm{L}, 100-1000 \mu \mathrm{L})$ (NEPTUNE); Analytical Balance (AXIS); Tube effendorf 1,5 mL (SPL 60015-1); Vortec (WiseMix VM-10); Biosafety Cabinet (BSC) (Telstar); Multiskan Go Reader (Thermo Fisher Scientific 1510); 96 well plate (TPP 92096); Falcon tube 15 mL (SPL 50015); Falcon Tube 50 mL (SPL 50050); Cawan Petri Disposabble; Sentrifuge; Serological Pipet; Filter 0.45 mM; Filter $0.22 \mathrm{mM}$; dan Syringe.

Bahan yang dipergunakan dalam penelitian ini adalah: Ekstrak daun ketepeng cina (Cassia alata L.); Candida albicans ATCC 10231; Potato Dextrose Agar (PDA); Potato Dextrose Brtoth (PDB); dan Nistatin. Jenis penelitian yang digunakan yaitu bersifat eksperimental murni laboratorium secara in vitro menggunakan teknik Broth Microdilution. Metode yang digunakan dalam penelitian ini sesuai dengan metode yang dikembangkan oleh CLSI (Clinical Laboratory Standard Institute, 2008) dengan sedikit modifikasi. 69

Penelitian terdiri dari sembilan perlakuan dengan dilakukan uji pendahuluan terlebih dahulu, maka didapatkan tujuh perlakuan dari bahan coba ekstrak etanol daun ketepeng cina dengan konsentrasi $200 \mathrm{mg} / \mathrm{mL} ; 100 \mathrm{mg} / \mathrm{mL} ; 50 \mathrm{mg} / \mathrm{mL} ; 25 \mathrm{mg} / \mathrm{mL} ; 12,5 \mathrm{mg} / \mathrm{mL} ; 6,25 \mathrm{mg} / \mathrm{mL}$ dan 3,125 mg/mL.; kontrol negatif menggunakan Potato Dextrose Broth (PDB) dan DMSO 10\% 
dengan Candida albicans, dan kontrol positif menggunakan Potato Dextrose Broth (PDB) ditambahkan nistatin dengan Candida Albicans.

Pengamatan dilakukan dengan mengamati tingkat kekeruhan dari setiap tabung untuk menentukan kadar hambat minimum (KHM) menggunakan alat spektrofotometri pada jam ke 0 dan jam ke 24 kemudian menghitung jumlah koloni dari setiap well plate flat round untuk menentukan kadar bunuh minimum (KBM) menggunakan alat Colony counter.

Data yang dinilai adalah kadar hambat minimum (KHM) ekstrak etanol daun ketepeng cina dengan konsentrasi $200 \mathrm{mg} / \mathrm{mL} ; 100 \mathrm{mg} / \mathrm{mL} ; 50 \mathrm{mg} / \mathrm{mL} ; 25 \mathrm{mg} / \mathrm{mL} ; 12,5 \mathrm{mg} / \mathrm{mL} ; 6,25 \mathrm{mg} / \mathrm{mL}$ dan $3,125 \mathrm{mg} / \mathrm{mL}$ dalam menghambat pertumbuhan Candida albicans yang diuji menggunakan uji one way ANOVA di mana hasil dianggap signifikan bila nilai $\mathrm{p}<0,05$.

\section{Hasil}

\section{Hasil Uji Fitokimia Daun Ketepeng Cina}

Hasil uji fitokimia untuk mengetahui senyawa yang terdapat dalam daun ketepeng cina, hasil dari uji fitokimia dapat dilihat pada Tabel 1.

Tabel 1 Hasil Uji Fitokimia Daun Ketepeng Cina

\begin{tabular}{cccc}
\hline No. & Metabolit Sekunder & Metode Uji & Hasil Uji \\
\hline 1. & Fenolik & Pereaksi FeCl $5 \%$ & + \\
2. & Tannin & Pereaksi FeCl $31 \%$ & + \\
3. & Flavonoid & a. Pereaksi HCl pekat $+\mathrm{Mg}$ & + \\
& & b. Pereaksi $\mathrm{H}_{2} \mathrm{SO}_{4} 2 \mathrm{~N}$ & - \\
& & c. Pereaksi NaOH $10 \%$ & + \\
4. & Saponin & Dipanaskan & + \\
5. & Triterpenoid dan Steroid & Pereaksi $\mathrm{H}_{2} \mathrm{SO}_{4}+\mathrm{CH} 3 \mathrm{COOH}$ & + \\
& & anhidrat & - \\
6. & Alkaloid & a. Pereaksi Dragendorff & + \\
& & b. Pereaksi Mayer & - \\
\hline
\end{tabular}

Setelah dilakukan uji fitokimia daun ketepeng cina maka menunjukkan hasil bahwa daun ketepeng cina positif mengandung senyawa fenolik, tannin, flavonoid, saponin, triterpenoid, dan alkaloid.

Penelitian ini merupakan penelitian eksperimental laboratorium dengan menggunakan metode Broth Microdilution untuk mengetahui Kadar Hambat Minimum (KHM) dari ekstrak etanol daun ketepeng cina (Cassia alata L.) terhadap pertumbuhan Candida albicans. 
Hasil analisis kadar hambat dikuantifikasikan dengan dilakukan uji spektrofotometri pada panjang gelombang $530 \mathrm{~nm} .^{70}$ Hasil spektrofotometri sebagai berikut:

Tabel 2 Hasil Uji Spektrofotometri pada Panjang Gelombang $530 \mathrm{~nm}$

\begin{tabular}{lccccccc}
\hline \multirow{2}{*}{ Perlakuan } & \multicolumn{3}{c}{ Absorbansi Jam 0 } & \multicolumn{3}{c}{ Absorbansi Jam 24 } & Abs. Jam \\
\cline { 2 - 7 } & Rerata & $\begin{array}{c}\text { St. } \\
\text { Dev }\end{array}$ & $\begin{array}{c}\text { RSD } \\
(\%)\end{array}$ & Rerata & $\begin{array}{c}\text { St. } \\
\text { Dev }\end{array}$ & $\begin{array}{c}\text { RSD } \\
(\%)\end{array}$ & $\begin{array}{c}\text { Jam 0 } \\
\text { Jabs. }\end{array}$ \\
\hline Kontrol Negatif & 0,07 & 0,00 & 1,47 & 0,15 & 0,02 & 15,82 & 0,08 \\
Ekstrak 200 mg/mL & 3,30 & 0,07 & 2,06 & 3,97 & 0,05 & 1,38 & 0,67 \\
Ekstrak 100 mg/mL & 1,59 & 0,01 & 0,35 & 2,35 & 0,03 & 1,14 & 0,75 \\
Ekstrak 50 mg/mL & 0,76 & 0,01 & 1,35 & 1,10 & 0,02 & 1,76 & 0,34 \\
Ekstrak 25 mg/mL & 0,42 & 0,00 & 1,18 & 0,65 & 0,02 & 2,51 & 0,23 \\
Ekstrak 12,5 mg/mL & 0,24 & 0,00 & 1,57 & 0,37 & 0,01 & 2,65 & 0,12 \\
Ekstrak 6,25 mg/mL & 0,16 & 0,00 & 1,98 & 0,25 & 0,01 & 5,85 & 0,08 \\
Ekstrak 3,125 mg/mL & 0,12 & 0,00 & 2,19 & 0,23 & 0,02 & 8,30 & 0,11 \\
Nistatin & 2,24 & 0,13 & 5,64 & 2,22 & 0,01 & 4,31 & $-0,02$ \\
\hline
\end{tabular}

Berdasarkan tabel di atas diketahui terdapat peningkatan nilai absorbansi pada seluruh perlakuan karena adanya pertumbuhan yeast. Nilai absorbansi tertinggi pada konsentrasi ekstrak 200 mg/mL dengan rerata nilai absorbansi Jam $0(3,30)$ dan Jam 24 (3,97) sedangkan nilai absorbansi terendah pada konsentrasi ekstrak $3,125 \mathrm{mg} / \mathrm{mL}$ dengan rerata nilai absorbansi Jam $0(0,12)$ dan Jam $24(0,23)$. Nilai absorbansi tidak dapat dijadikan patokan untuk aktivitas penghambatan dikarenakan tingkat kekeruhan ekstrak yang berbeda pada setiap konsentrasi, maka dilakukan penghitungan yeast melalui Total Plat Count (TPC).

Tabel 3. Jumlah Yeast setelah Inkubasi 24 jam pada Berbagai Konsentrasi Ekstrak Daun Ketepeng Cina

\begin{tabular}{llllllll}
\hline \multicolumn{1}{c}{ Perlakuan } & \multicolumn{3}{c}{ Jumlah Yeast (CFU/mL } & $\begin{array}{l}\text { Rerata } \\
\text { (CFU) }\end{array}$ & St. Dev & RSD \\
\hline Kontrol Negatif & 1270000 & 1060000 & 1130000 & 1050000 & 1.127 .500 & 101447,9 & 9,00 \\
Nistatin & 0 & 0 & 0 & 0 & 0 & 0 & 0 \\
Ekstrak 200 mg/mL & 47000 & 44000 & 40000 & 43000 & 43.500 & 2886,751 & 6,64 \\
Ekstrak 100 mg/mL & 105000 & 114000 & 112000 & 90000 & 105.250 & 10874,28 & 10,33 \\
Ekstrak 50 mg/mL & 248000 & 244000 & 234000 & 244000 & 242.500 & 5972,158 & 2,46 \\
Ekstrak 25 mg/mL & 292000 & 286000 & 275000 & 281000 & 283.500 & 7234,178 & 2,55 \\
Ekstrak 12,5 mg/mL & 850000 & 710000 & 680000 & 660000 & 725.000 & 85829,29 & 11,84 \\
Ekstrak 6,25 mg/mL & 930000 & 910000 & 900000 & 940000 & 920.000 & 18257,42 & 1,98 \\
Ekstrak 3,125 mg/mL & 1020000 & 970000 & $\underline{950000}$ & 1010000 & $\underline{987.500}$ & $\underline{33040,38}$ & $\underline{3,35}$ \\
\hline
\end{tabular}


Berdasarkan Tabel 3 diketahui rata-rata jumlah yeast yang paling kecil terdapat pada konsentrasi ekstrak $200 \mathrm{mg} / \mathrm{mL}$ dengan rerata $43.500 \mathrm{CFU} / \mathrm{mL}$ (Colony Forming Unit/mL) dengan cara perhitungan jumlah yeast pada pengulangan pertama ditambah kedua ditambah ketiga ditambah keepat kemudian dibagi empat, maka dari itu dalam konsentrasi tersebut terjadi pertumbuhan yeast yang rendah jika dibandingkan dengan konsentrasi ekstrak $100 \mathrm{mg} / \mathrm{mL} ; 50$ $\mathrm{mg} / \mathrm{mL} ; 25 \mathrm{mg} / \mathrm{mL} ; 12,5 \mathrm{mg} / \mathrm{mL} ; 6,25 \mathrm{mg} / \mathrm{mL} ;$ dan 3,125 mg/mL.

Tabel 4 Persen Penghambatan Pertumbuhan Candida albicans oleh Ekstrak Daun Ketepeng Cina

\begin{tabular}{llllllll}
\hline \multicolumn{1}{c}{ Perlakuan } & \multicolumn{9}{c}{ \% Penghambatan } & Rerata & St. Dev & RSD \\
\hline Nistatin & 100 & 100 & 100 & 100 & 100 & 0 & 0 \\
Ekstrak 200 mg/mL & 95,83 & 96,10 & 96,45 & 96,19 & 96,14 & 0,26 & 0,00 \\
Ekstrak 100 mg/mL & 90,69 & 89,89 & 90,07 & 92,02 & 90,67 & 0,96 & \\
Ekstrak 50 mg/mL & 78,00 & 78,36 & 79,25 & 78,36 & 78,49 & 0,53 & 0,01 \\
Ekstrak 25 mg/mL & 74,10 & 74,63 & 75,61 & 75,08 & 74,86 & 0,64 & 0,0 \\
Ekstrak 12,5 mg/mL & 24,61 & 37,03 & 39,69 & 41,46 & 35,70 & 7,61 & 0,21 \\
Ekstrak 6,25 mg/mL & 17,52 & 19,29 & 20,18 & 16,63 & 18,40 & 1,62 & 0,09 \\
Ekstrak 3,125 mg/mL & 9,53 & 13,97 & 15,74 & 10,42 & 12,42 & 2,93 & 0,24 \\
\hline
\end{tabular}

Berdasarkan Tabel 4 diketahui bahwa persen penghambatan yang paling mempengaruhi pertumbuhan Candida albicans yaitu pada konsentrasi ekstrak $200 \mathrm{mg} / \mathrm{mL}$ dengan rerata $96,14 \%$ sedangkan pada konsentrasi ekstrak 3,125 mg/mL dengan rerata $12,42 \%$ tidak menunjukkan penghambatan yang baik terhadap pertumbuhan Candida albicans.

\section{$\underline{\text { Hasil Analisis Statistik }}$}

Tabel 5 berisikan jumlah yeast setelah diberi perlakuan ekstrak etanol daun ketepeng cina (Cassia alata L.) selama waktu perlakuan 24 jam.

Tabel 5 Hasil Statistik Jumlah Yeast setelah Inkubasi 24 Jam

\begin{tabular}{lc}
\hline \multicolumn{1}{c}{ Perlakuan } & Rerata Jumlah Yeast $(\mathrm{CFU} / \mathrm{mL})$ \\
\hline Kontrol Negatif & $1.127 .500 \pm 101.447 .9^{\mathrm{f}}$ \\
Nistatin & $0 \pm 0.00^{\mathrm{g}}$ \\
Ekstrak $200 \mathrm{mg} / \mathrm{mL}$ & $43.500 \pm 2.886,75^{\mathrm{a}}$ \\
Ekstrak $100 \mathrm{mg} / \mathrm{mL}$ & $105.250 \pm 10.874,28^{\mathrm{b}}$ \\
Ekstrak $50 \mathrm{mg} / \mathrm{mL}$ & $242.500 \pm 5.972,15^{\mathrm{c}}$ \\
Ekstrak $25 \mathrm{mg} / \mathrm{mL}$ & $283.500 \pm 7.234,17^{\mathrm{c}}$ \\
Ekstrak $12,5 \mathrm{mg} / \mathrm{mL}$ & $725.000 \pm 85.829,29^{\mathrm{d}}$ \\
Ekstrak $6,25 \mathrm{mg} / \mathrm{mL}$ & $920.000 \pm 18.257,42^{\mathrm{e}}$ \\
Ekstrak $3,125 \mathrm{mg} / \mathrm{mL}$ & $987.500 \pm 330.40,38^{\mathrm{f}}$ \\
\hline
\end{tabular}


Hasil penelitian menunjukkan terdapat efek dari pemberian ekstrak etanol daun ketepeng cina mempengaruhi jumlah yeast sehingga jumlah yeast mengalami penurunan setelah diberikan ekstrak dengan berbagai konsentrasi selama 24 jam. Pada konsentrasi ekstrak 200 $\mathrm{mg} / \mathrm{mL}$ dengan rerata jumlah yeast $43.500 \mathrm{CFU} / \mathrm{mL}$, hal ini terbukti adanya penurunan jumlah yeast jika dibandingkan dengan kontrol negatif dengan jumlah yeast $1.127 .500 \mathrm{CFU} / \mathrm{mL}$, sedangkan dalam konsentrasi ekstrak 3,125 mg/mL juga terdapat sedikit penurunan dengan jumlah yeast $987.500 \mathrm{CFU} / \mathrm{mL}$. Dengan demikian semakin tinggi konsentrasi ekstrak maka jumlah yeast semakin menurun.

Tabel 6 Hasil Statistik Penghambatan Pertumbuhan Candida albicans oleh Ekstrak Cassia alata L.

\begin{tabular}{lc}
\hline \multicolumn{1}{c}{ Perlakuan } & $\begin{array}{c}\text { Persen Penghambatan } \\
(\%)\end{array}$ \\
\hline Nistatin & $100 \pm 0.00^{\mathrm{a}}$ \\
Ekstrak $200 \mathrm{mg} / \mathrm{mL}$ & $96,14 \pm 0,26^{\mathrm{b}}$ \\
Ekstrak $100 \mathrm{mg} / \mathrm{mL}$ & $90,67 \pm 0,96^{\mathrm{c}}$ \\
Ekstrak $50 \mathrm{mg} / \mathrm{mL}$ & $78,49 \pm 0,53^{\mathrm{d}}$ \\
Ekstrak $25 \mathrm{mg} / \mathrm{mL}$ & $74,86 \pm 0,63^{\mathrm{e}}$ \\
Ekstrak $12,5 \mathrm{mg} / \mathrm{mL}$ & $35,70 \pm 7,61^{\mathrm{f}}$ \\
Ekstrak $6,25 \mathrm{mg} / \mathrm{mL}$ & $18,40 \pm 1,62^{\mathrm{g}}$ \\
Ekstrak $3,125 \mathrm{mg} / \mathrm{mL}$ & $12,42 \pm 2,93^{\mathrm{h}}$ \\
\hline
\end{tabular}

Hasil penelitian pada Tabel 5 telah menunjukkan bahwa konsentrasi ekstrak $200 \mathrm{mg} / \mathrm{mL}$ dapat menghambat pertumbuhan Candida albicans yang mampu menurunkan jumlah yeast menjadi 43.500 dari 1.127.500 maka dari itu dari Tabel 6 menunjukkan bahwa konsentrasi ekstrak $200 \mathrm{mg} / \mathrm{mL}$ dapat menghambat pertumbuhan Candida albicans sebesar 96,14\%.

\section{Diskusi}

Hasil uji fitokimia ekstrak etanol daun ketepeng cina (Cassia alata L.) mengandung senyawa fenolik, tannin, flavonoid, saponin, triterpenoid, steroid, dan alkaloid. Hasil yang didapat sesuai dengan hasil penelitian sebelumnya yang telah dilakukan oleh Yakubu, et. al. (2010) dimana ekstrak etanol daun ketepeng cina (Cassia alata L.) positif mengandung fenolik 0,44\%; flavonoid $1,06 \%$; saponon $1,22 \%$; dan alkaloid $0,52 \% .{ }^{61}$

Berdasarkan hasil penelitian diperoleh bahwa jumlah yeast yang paling kecil pada konsentrasi $200 \mathrm{mg} / \mathrm{mL}$ dengan jumlah yeast $43.500 \mathrm{CFU} / \mathrm{mL}$ dibandingkan dengan kontrol negatif dengan jumlah yeast 1.127.500 CFU/mL. Hasil analisis statistik diketahui jika jumlah 
yeast pada setiap perlakuan yang telah diberikan ekstrak etanol daun ketepeng cina memiliki perbedaan yang bermakna kecuali pad konsentrasi ekstrak $50 \mathrm{mg} / \mathrm{mL}$ dengan jumlah yeast 242.500 CFU/mL dan $25 \mathrm{mg} / \mathrm{mL}$ dengan jumlah yeast $283.500 \mathrm{CFU} / \mathrm{mL}$ karena konsentrasi tersebut memiliki efek yang sama terhadap jumlah yeast.

Hasil analisis menunjukkan bahwa persen penghambtan yang paling tinggi pada konsentrasi $200 \mathrm{mg} / \mathrm{mL}$ yaitu 96,14\% dibandingkan dengan kontrol positif 100\% sedangkan hasil analisis statistik diketahui jika persen penghambatan pada berbagai konsentrasi ekstrak etanol daun ketepeng cina memiliki perbedaan yang bermakna, yang artinya setiap perlakuan ekstrak menghasilkan persen penghambatan yang berbeda terhadap pertumbuhan Candida albicans.

Penelitian ini menunjukkan bahwa ekstrak etanol daun ketepeng cina (Cassia alata L.) memiliki aktivitas antijamur disebabkan karena adanya senyawa-senyawa metabolit sekunder yang mempunyai aktivitas antijamur seperti fenolik, tannin, flavonoid, saponin, triterpenoid, steroid, dan alkaloid.

Jamur mempunya struktur dinding sel yang sangat kompleks dengan rangka dasar yang terdiri dari polisakarida kristalin, kitin, dan b-glukan, serta adanya suatu matrik yang terdiri dari polisakarida amorf dan kompleks proteinsakarida. Kitin dan b-glukan bertanggung jawab terhadap mekanisme dinding sel jamur. Djunaedy (2008) menyatkan bahwa senyawa antijamur memiliki mekanisme kerja dengan cara menetralisasi enzim yang terkait dalam invasi jamur, merusak membran sel jamur, menghambat sistem enzim jamur sehingga mengganggu terbentuknya ujung hifa dan mempengaruhi sistesis asam nukleat dan protein. ${ }^{62}$

Hasil penelitian oleh Nurhidayah (2014) menunjukkan bahwa ekstrak metabolit sekunder alkaloid dan flavonoid memiliki efektivitas sebagai antijamur terhadap jamur Candida albicans. $^{63}$

Flavonoid merupakan kelompok senyawa terbesar di alam yang dikenal sebagai antioksidan yang memiliki efek sebagai antibakteri dan antifungi karena mengandung gugus fenol serta memiliki fungsi mendenaturasi protein sel jamur dan bersifat lipofilik. Mekanisme kerja flavonoid dengan cara mendenaturasi protein dan mengganggu lapisan lipid sehingga mengakibatkan kerusakan dinding sel. Sifat lipofilik pada flavonoid tersebut yang akan mengikat fosfolipid-fosfolipid pada membran sel jamur dan mengganggu permeabilitas membran sel sehingga membran sel menjadi lisis dan senyawa tersebut menembus ke dalam inti sel sehingga menyebabkan jamur tidak berkembang. ${ }^{64,65}$

Tannin adalah senyawa aktif yang berperan sebagai antijamur. Tannin mempunyai sifat sebagai pengelat berefek spasmolitik yang mengerutkan usus sehingga gerakan peristaltik usus menjadi berkurang. Efek spasmolitik ini diduga dapat mengerutkan dinding sel jamur Candida 
albicans, sehingga mengganggu permeabilitas sel, maka sel tidak dapat melakukan aktivitas hidupnya yang akhirnya menyebabkan pertumbuhan sel terhambat atau bahkan sel akan mati. Mekanisme antijamur yang dimiliki tannin adalah karena kemampuannya menghambat kitin yang digunakan untuk pembentukan dinding sel jamur dan merusak membran sel sehingga pertumbuhan jamur terhambat.64,66

Senyawa saponin berkontribusi sebagai antijamur dengan cara mengganggu stabilitas membran sel. Stabilitas membran sel terganggu akan meningkatkan permeabilitas yang mengakibatkan cairan intraseluler tertarik keluar sel sehingga nutrisi, zat-zat metabolisme, enzim, dan protein dalam sel keluar dan jamur mengalami kematian. ${ }^{67}$ Terpenoid termasuk triterpenoid merupakan senyawa bioaktif yang memiliki fungsi sebagai antijamur. Terpenoid ini dapat menghambat pertumbuhan jamur, baik melalui membran sitoplasma amupun mengganggu pertumbuhan dan perkembangan spora jamur. ${ }^{68}$

Pada penelitian ini didapatkan hasil bahwa pada berbagai konsentrasi ekstrak etanol daun ketepeng cina dapat menghambat Candida albicans. Pada konsentrasi $200 \mathrm{mg} / \mathrm{mL}$ adalah konsentrasi yang menghasilkan jumlah yeast paling kecil dan persen penghambatan yang paling tinggi. Dengan demikian dapat disimpulkan bahwa konsentrasi $200 \mathrm{mg} / \mathrm{mL}$ cukup efektif dalam menghambat pertumbuhan Candida albicans serta semakin tinggi konsentrasi ekstrak semakin rendah pula jumlah yeast. Namun jumlah yeast dan persen penghambatan yang dihasilkan oleh kontrol positif nistatin masih lebih baik dibandingkan dengan ekstrak etanol daun ketepeng cina dengan konsentrasi $200 \mathrm{mg} / \mathrm{mL}$. Maka dari itu penggunaan nistatin masih lebih baik dibandingkan dengan ekstrak etanol daun ketepeng cina (Cassia alata L.). Akan tetapi pada nistatin dapat menimbulkan efek samping seperti mual dan muntah, sedangkan pada ekstrak etanol daun ketepeng cina (Cassia alata L.) jika diolah dengan baik dan benar maka efek samping yang dihasilkan akan berkurang. Sehingga penggunaan ekstrak etanol daun ketepeng cina (Cassia alata L.) dapat digunakan sebagai tindakan pencegahan.

\section{Kesimpulan}

Ekstrak etanol daun ketepeng cina (Cassia alata L.) dapat menghambat pertumbuhan Candida albicans pada konsentrasi $200 \mathrm{mg} / \mathrm{mL}$; dan Ekstrak etanol daun ketepeng cina (Cassia alata L.) tdak dapat membunuh pertumbuhan Candida albicans. 


\section{Referensi}

1. Nur'aeny N, Hidayat W, Dewi TS, Herawati E, Wahyuni IS. Profil Oral Candidiasis di Bagian Ilmu Penyakit Mulut RSHS Bandung Periode 20102014. Majalah Kedokteran Gigi Indonesia. 2017;3(1):23-8.

2. Williams, Lewis David, Michael. Pathogenesis and treatment of $\quad$ oral candidosis. Journal of oral microbiology. 2011;3(1):5771.

3. Nasution AI. Virulence factor and pathogenicity of Candida albicans in oral candidiasis.

World journal of dentistry. 2013;4(4):267-71.

4. Neville B. Oral \& Maxillofacial Pathology. 2nd ed. Philadelphia: W.B. Saunders Company; 2002.

5. Scully C. Handbook of Oral Disease Diagnosis and Management. United Kingdom: Martin Dunitz; 1999.

6. Gnanasundaram N. Key to diagnose HIV/AIDS clinically through its oral manifestations.

Journal of Indian Academy of Oral Medicine and Radiology. 2010;22(3):119.

7. Rachimhadhi $\mathrm{T}$, Anthony R, Hendarmin S. Sindroma AIDS: penanggulangan penyebarannya dalam praktek dokter gigi. Jakarta: EGC. 1992:28-32.

8. BW. N. Oral \& Maxillofacial Pathology. 2 ed. Philadelphia: W.B. Saunders Company; 2002.

9. Andriani R, Rundjan L. Nistatin Oral Sebagai Terapi Profilaksis Infeksi Jamur Sistemik pada Neonatus Kurang Bulan. Sari Pediatri. 2016;11(6):420-27.

10. Joyce Kee ER, dan Hayes. Farmakologi Pendekatan Proses Keperawatan. Jakarta: EGC; 2014.

11. Bhaskara GY. Uji Daya Antifungi Ekstrak Etanol Daun Salam (Syzygium polianthum [Wight] Walp.) Terhadap Candida albicans ATCC 10231 Secara In Vitro: Universitas Muhammadiyah Surakarta; 2012.

12. Greenberg MS. Burket's Oral Medicine. 11th ed. Hamilton Ontario: Bc Decker Inc; 2008.

13. Don Sheppard M \& Harry W LD. Antijamur Agents. Basic \& Clinical Pharmacology. 11th e d. 2009.

14. Edo T. Uji Daya Hambat Ekstrak Etanok Daun Ketepeng Cina (Cassia alata L. ) Terhadap Pertumbuhan Jamur Trichophyton sp. secara In Vitro. Jurnal Ilmiah Mahasiswa Veteriner. 2017;1(1).

15. Hidayat S. Kitab Tumbuhan Obat. Jakarta: AgriFlo (Penebar Swadaya Grup); 2015.

16. Murni M, Gunawan G, Janitra B. Effectiveness of Ketepeng (Cassia Alata L) and Small Ketepeng (Cassia Tora L) Ethanol Extract on Plasmodium Falciparum in Vitro. Balaba: Jurnal. Litbang Pengendalian Penyakit Bersurnber Binatang Banjarnegara. 2014;10(2 Des): 83-8.

17. Senthilkumar R, Malayaman V, Sindhuja S. Phytochemical screening and antibacterial evaluation of the leafflower and seed coat extracts of Cassia alata L. Journal of Chemical and Pharmaceutical Research. 2013,5(11):740- 4.

18. Timothy S, Wazis C, Zakama S, Dawurung J, Albert T. Antipyretic Activity of 
Aqueous and Ethannolic Extract of Cassia alata Linn Leaf International Journal of Research in Ayurveda \& Pharmacy. 2012;3(5).

19. Rahmawati R, Muflihunna A, Kusuma AT. Analisis Kadar Flavonoid dan Fenolik Total Fraksi Etil Asetat Daun Ketepeng Cina (Senna alata (L.) Roxb) Dengan Metode Spektrofotometri UV-Visible As-Syifaa Jurnal Farmasi. 2015;7(1):10-8.

20. Gama AMP, Subakir 5, Suhardjono S. Perbandingan Ekstrak Daun Ketepeng Cina (Cassia alata Linn) dengan Ketokonazol 2\% dalam Menghambat Pertumbuhan Malessezia furfur pada Pityriasis versicolor secara In Vitro: Faculty of Medicine; 2011.

21. Bahi M, Mutia R, Mustanir M, Lukitaningsih E. Bioassay on n-Hexane Extract of Leaves Cassia alata against Candida albicans. Jurnal Natural. 2014;14(1).

22. Jawetz E, Melnick, J. L., Adelberg, F. A. Mikrobiologi Kedokteran. Edisi XXII ed. Jakarta: Salemba Medika; 2005.

23. Hakim L, Ramadhian MR. Kandidiasis oral. Jurnal Majority. 2015;4(9):53-7.

24. Saputra. Pengaruh Jenis Pelarut Terhadap Jumlah Ekstrak dan Daya Antifungi Daun Ketepeng Cina (Cassia alata L) Terhadap Jamur Trychophyton sp Universitas Islam Negeri Sultan Syarif Kasim Riau; 2014.

25. Didik G, Mulyani, Sri. Ilmu Obat Alam (Farmakognosi) Mid I. Jakarta: Penebar Swadaya. 2004.

26. Anwar AND. Manfaat Daun Ketepeng Cina (Cassia alata L.) sebagai Antifungi pada Tinea Pedis. Jurnal Agromedicine. 2015;2(4):385-8.

27. Ganiswarna SG SR, Suryatna FD, Purwantyastuti, Suyatna N. Farmakologi dan Terapi. 4 ed. Jakrta: Fakultas Kedokteran U1 2004.

28. JM A. Determination of minimum inhibitory concentrations; 2002.

29. Learning L. Boundless Microbiology Measuring Drug Susceptibility.

30. Sykes JE. Canine and Feline Infectious Diseases: Elsevier; 2014.

31. Navigator C. Minimum Bactericidal Concentration (MBC); 2018.

32. Linda R. Aktivitas Ekstrak Daun Ketepeng Gina (Cassia alata Linn.) Terhadap Pertumbuhan Jamur Cercospora personatum. Biopropal Industri. 2011;02.

33. Hujjatusnaini N. Uji Potensi Ekstrak Daun Ketepeng Cina (Cassia alata L.) Terhadap Penghambatan Pertumbuhan Trichophyton sp. 2012.

34. Fajri M. Aktivitas Antifungi Daun Ketepeng Cina (Cassia alata L.) Fraksi Etanol, N- Heksa, dan Kloroform Terhadap Jamur Microsporium canis. Pharmaceutical Journal Of Islamic Pharmacy. 2018;2.

35. Mahmudah R. Uji Efektifitas Ekstrak Etanol Pada Daun Ketepeng Cina (Cassia alata L.) Terhadap Mikroba Penyebab Sariawan (Stomatitis Apthosa). Jurnal Mandala Pharmacon Indonesia. 2018;4.

36. Aquariushinta N. Formulasi dan Uji Stabilitas Fisik Sediaan Gel Ekstrak Daun Ketepeng Cina (Cassia alata L.). Jurnal Kefarmasian Indonesia. 2015;5.

37. Nurlansi. Uji Aktivitas Antibakteri Ekstrak Metanol dan Fraksi Etilasetat Daun Ketepeng Cina (Cassia alata L.). Indonesia Natural Research Pharmaceutical Journal. 2017;2.

38. Triana. Aktivitas Antijamur Ekstrak Daun Ketepeng Cina (Cassia alata L.). Jurnal Sains dan Kesehatan. 2017;1.

39. Mutiawati VK. Pemeriksaan Mikrobiologi Pada Candida albicans. Jurnal Kedokteran Syiah Kuala. 2016.

40. Salerno C. Candida-associated denture stomatitis. Journal section: Oral 
Medicine and Pathology. 2011.

41. Komariah SR. Kolonisasi Candida dalam Rongga Mulut. Majalah Kedokteran FK UKI. 2012.

42. Samaranayake L. Essential Microbiology For Dentistry. 4th ed: Churchill Livingstone Elsevier; 2012.

43. Jawetz E, Melnick, J. L., Adelberg, F. A. Mikrobiologi Kedokteran. Jakarta: Buku Kedokteran EGC; 2008.

44. Dian H. Candida albicans. 2008.

45. William D. Pathogenesis and Treatment of Oral Candidosis. Journal of Oral Microbiology. 2011.

46. Kusumaningtyas E. Mekanisme Infeksi Candida albicans Pada Permukaan Sel. Lokakarya Nasional Penyakit Zoonosis. Balai Penelitian Veteriner. 2007.

47. Cannon RD, Chaffin W. Colonization is a crucial factor in oral candidiasis. Journal of dental education. 2001;65(8):785-7.

48. A Akpan, Morgan R. Oral Candidiasis. Postgrad Med. 2002.

49. Hani U. Candidiasis: A Fungal Infection- Current Challenges and Progress in Prevention and Treatment. Department of Pharmaceutics, JSS College of Pharmacy. 2015.

50. JB Epstein KI. Oral candidiasis: pathogenesis and host defense. 2014.

51. Scully C. Candida and oral candidosis. 2004.

52. Bondaryk M. Antifungal agents commonly used in the superficial and mucosal candidiasis treatment: mode of action and resistance development. National Institute of Public Health. 2013.

53. Kee JL. Farmakologi: Pendekatan Proses Keperawatan. Jakarta: Kedokteran EGC; 1996.

54. Khan F. In Vitro Antifungal Sensivity of Fluconazole, Clotrimazole and Nystatin Againts Vaginal Candidiasis In Females of Childbearing Age. 2010.

55. Setiabudy R. Farmakologi dan Terapi 4th ed. Jakarta: Gaya Baru; 2005.

56. Novilla A, Nursidika P, Resmelia M. Potensi Asam Lemak Pada Minyak Kelapa Murni Dalam Menghambat Candida Albicans Secara In Vitro. Majalah Kedokteran Bandung. 2016;48(4):200-4.

57. Gunawan SG. Farmakologi dan Terapi 5th ed. Jakarta: Gaya Baru; 2007.

58. Sujarweni VW. Statistik Untuk Kesehatan. Yogyakarta: Gava Media; 2015.

59. Simatupang MM. Candida albicans. Candida Albicans. 2009.

60. Departemen Kesehatan Ri Direktorat Jenderal Pengawasan Obat dan Makanan. Parameter Standar Umum Ekstrak Tumbuhan Obat. Jakarta: Departemen Kesehatan; 2000.

61. Rahmawati, A.Muflihunna, Kusuma AT, Hardiyanti. Analisis Kadar Flavonoid dan Fenolik Total Fraksi ail Asetat Daun Ketepeng Cina (Senna alata L. ) Roxb) dengan Metode Sprektrofotometri UV-Visible. Jurnal AsSyifaa. 2015;7.

62. Djunaedy A. Aplikasi Fungisida Sistemik dan Pemanfaatan Mikoriza dalam Rangka Pengendalian Patogen Tular Tanah pada Tanaman Kedelai (Glycine max L. ). Jurnal Embryo. 2008;5.

63. Nurhidayah, Hasanah U, Idramsa. Pengaruh Ekstrak Metabolit Sekunder Jamur Endofit Tumbuhan Cotylelobium melanoxylon dalam Menghambat Pertumbuhan Mikroba Patogen. Jurnal Biosains. 2014;1.

64. Putri AMS. Efek Antifungi Ekstrak Daun Kenikir (Cosmoc caudatus Kunth.) Terhadap Pertumbuhan Candida albicans secara in Vitro. 2016. 
65. Sulistyawati. Uji Aktivitas Antijamur Infusa Daun Jambu Mete (Anacardium occidentale, L.) Terhadap Candida albicans. 2009;2.

66. Suraini, Chairani, Enlita. Uji Aktivitas Antijamur Ekstrak Gambir (UncariagambirRoxb) terhadap Candida albicans secara in Vitro. Scienta. 2015;5.

67. Aniszewski T. Alkaloids - Secret of Life. Finnland: Elsevier. 2007.

68. Lutfiyani R, Ma'ruf WF, Dewi EN. Aktivitas Antijamur Senyawa Bioaktif Ekstrak Gelidium latifolium Terhadap Candida albicans. Jumal Pengolahan dan Bioteknologi Hasil Perikanan. 2012.

69. CLSI (Clinical Laboratory Standard Institute). Reference Method for Broth Dilution Antifungal Susceptibility Testing of Yeasts; Approved StandardThrid Edition. CLS1 document M27-A2. Wayne, PA: Clinical Laboratory Standard Institute. 2008.

70. Lee, J.A. and Chee, H.Y. In vitro antifungal activity of equol against Candida albicans. Mycrobiology, 38(4). 2010.

71. Jabalameli Z, Mohammad A, dkk. Antifungal Susceptibility of Candida Species Isolated from Cancer Patients with Oral Lesions Undergoing Chemotherapy. International Journal of Infection. 2017. 